\title{
EFFECT OF DIGESTATE APPLICATION ON HERBAGE QUALITY AND QUANTITY OF PERMANENT GRASSLAND
}

\author{
ZUZANA KOVÁČIKOVÁ*, VLADIMÍRA VARGOVÁ, L'UBICA JANČOVÁ
}

\author{
Plant Production Research Center Piešt'any
}

KOVÁČIKOVÁ, Z. - VARGOVÁ, V. - JANČOVÁ, L.: Effect of digestate application on herbage quality and quantity of permanent grassland. Agriculture (Pol’nohospodárstvo), vol. 59, 2013, no. 2, pp. 88-98.

Possibilities were studied for using digested substrate as fertiliser applied to grassland. Over 2008-2009, a research trial consisting of four treatments in four replicates (the non-fertilised control; sward fertilized with digested substrates from $100 \%$ slurry; $80 \%$ slurry and $20 \%$ phytomass; $60 \%$ slurry and $40 \%$ phytomass) was performed on seminatural grassland at Radvaň site. In the sward utilised by three cuts a year, these parameters were studied: botanical composition, dominant species, herbage production, organic matter and mineral substances. At the fertilized treatments, the proportion of grasses was higher in 2009 than in 2008, but that of legumes and other herbs de- creased. Dominant grasses were Poa pratensis L., Festuca rubra L., Lolium perenne L., Trisetum flavescens L. while Trifolium repens $\mathrm{L}$. and Medicago falcata L. dominated among legume species. The application of digested substrate as fertiliser showed positive effects on herbage production, the highest increase was found at Treatment 4 where the digested substrate consisting of $60 \%$ slurry and $40 \%$ phytomass was applied. The highest amounts of crude protein $(\mathrm{CP})$, calcium $(\mathrm{Ca})$ and magnesium $(\mathrm{Mg})$ were recorded at the treatment with the digested substrate composed of $80 \%$ slurry and $20 \%$ phytomass applied.

Key words: digested substrate, co-fermentation, dry matter production, herbage quality, herbage quantity, permanent grassland

Grassland biomass is suitable in numerous ways for producing energy. It is well established as feedstock for biogas production. Grasslands provide a variety of essential environmental benefits such as carbon storage, habitat function, preservation of ground and surface water quality. When producing biogas from grassland these benefits will remain or even grow, providing appropriate grassland management is implemented. Grassland biomass is suitable in many ways for producing energy. Currently it is used in practice as a feedstock for biogas production and as solid biofuel for combustion (Prochnov et al. 2009).

Production of fertilisers has markedly decreased due to reduced livestock population in Slovakia. This is one of the reasons why a range of alternative forms of using organic wastes are coming forward with the objective to replenish deficient organic matter in soil. The biogas production by continuous anaerobic digestion of animal and plant waste brings biological sludge as a by-product utilisable as fertiliser. The production of biogas is not only an efficient way of obtaining energy from animal or plant biomass, but also an ecological disposal of waste coming from agricultural, industrial and food sector (Hanáčková \& Slamka 2008; Ondrejčíková et al. 2009).

Agriculture and food industries produce high quantities of organic residues which could be used as raw materials for biogas production. Anaerobic decomposition of organic material contributes to the reduction of residues and increases the energy value 
of farming by producing biogas, and utilizing digestate instead of using mineral fertilizers (Tani et al. 2006; Salminen et al. 2001; Wang et al. 2010). The organic residue after digestion, the digestate, is rich in plant nutrients and may be recycled back to agricultural land as an organic fertiliser (Braun 2007). Digestate utilisation can be environmentally beneficial since nutrient cycles can be closed and the need for mineral fertiliser reduced (Dieterich et al. 2012). Anaerobic digestion converts of major part of organic nitrogen to ammonia, which is then directly available to plants as nitrogen. Because of the different origins of raw material for biogas production, digestate contains $5.0-40.0 \mathrm{~g} / \mathrm{kg}$ of nitrogen, $0.7 \mathrm{~g} / \mathrm{kg}$ of phosphorus and $0.4 \mathrm{~g} / \mathrm{kg}$ of potassium (Lehtomaki et al. 2008; Wulf et al. 2002). The field application with digestate could reduce the need for applying mineral nitrogen fertilizers and it could decrease the ammonia volatilization and nitrate leaching, mitigating environmental impact (Voća et al. 2005). The digestate application can influence soil fertility and the yield and the quality of the plants (Tilvikiene et al. 2010).

This digestate, a by-product of continuous production of biogas, is odourless, harmless from the hygienic viewpoint, dark, amorphous, non-plastic heterogeneous suspension of colloidal and solid substances. Primarily, it is an instant source of nitrogen $(\mathrm{N})$ which can be physiologically exploited better than $\mathrm{N}$ from mineral fertilisers (Pospíšil et al. 2009). Due to the digestate $\mathrm{pH}$ value ranging from
7.6 to 8.5 , the soil acidity is not rising and phosphorus (P) utilisation is better Pospíšil et al. (2011). The alkalizing effect of biological sludge $(\mathrm{pH}=7.5)$ on the value of soil reaction was confirmed (Hanáčková \& Slamka 2008). The application of digested substrate reduces the demands on the need for fertilizers, greatly reduces the requirements for pesticides, improve the hydro-physical soil properties, which has positive impact of the total soil moisture regime (Voća et al. 2005).

The research results have shown that digestate is a well-balanced organic fertiliser with specific positive effects on the soil reaction. Moreover, it inhibits the weed seed germination and smells less than conventional slurry (Pospíšil \& Mano 2007).

Anaerobic decomposition of biodegradable materials could contribute to the development of renewable energy. If a biogas plant is available on a farm, it is possible to secure a continuous process biomass - biogas - biomass (Tilvikiene et al. 2011).

In Slovakia, the large results are not available on the influence of digestate on the yield and the quality phytomass of permanent grassland yet. There are only the results of the research, dealing with the influence of digestate on quantitative and qualitative parameters of crop plants on arable land (e.g. sunflower, maize, sugar beet).

Therefore the objective of this work was to determine new possibilities for using secondary raw materials generated in the biogas production as grassland nutrition.

Chemical properties of soil $(0.0-0.15 \mathrm{~m})$ before the trial period

\begin{tabular}{|l|c|}
\hline Chemical properties* & Depth $0.0-0.15 \mathrm{~m}$ \\
\hline $\mathrm{pH}$ & 7.2 \\
Organic carbon $[\mathrm{g} / \mathrm{kg}]$ & 21.3 \\
Total nitrogen $[\mathrm{g} / \mathrm{kg}]$ & 1.2 \\
Available phosphorus $[\mathrm{mg} / \mathrm{kg}]$ & 27.0 \\
Available potassium $[\mathrm{mg} / \mathrm{kg}]$ & 154.0 \\
Available magnesium $[\mathrm{mg} / \mathrm{kg}]$ & 483.0 \\
$\mathrm{C} / \mathrm{N}$ ratio & 17.7 \\
\hline
\end{tabular}

* Available phosphorus, potassium and magnesium - determined by Mehlich III (Mehlich 2002), total nitrogen content was determined according Kjeldahl 


\section{MATERIAL AND METHODS}

The research was conducted at seminatural grassland site (Radvaň - near Banská Bystrica; altitude $427 \mathrm{~m}$; the mountain ranges of "Kremnické vrchy" and "Starohorské vrchy"; warm to medium warm agro-climatic region; dry sub-region). Long-term mean rainfall over growing season is $431 \mathrm{~mm}$; longterm mean annual rainfall $819.5 \mathrm{~mm}$; mean daily temperature $8^{\circ} \mathrm{C}$ per year and $15.5^{\circ} \mathrm{C}$ over growing season. The soil at the research site was Leptic Cambisol Skeletic (WRB 2006). Some characteristics of the soil are given in Table 1.

The digested substrate used in the research trial originated from co-fermentation of plant and animal biomass by wet semi-continual process performed at the experimental biogas plant in Kolínany - a part of the Demonstration Farm of the Slovak University of Agriculture in Nitra. The digestate collected after the end of each co-fermentation batch was applied to sward in the spring ( $40 \mathrm{~kg} \mathrm{~N} / \mathrm{ha})$ and after the first cut ( $20 \mathrm{~kg} \mathrm{~N} / \mathrm{ha})$, respectively (Table 2$)$. The application rates of $\mathrm{N}[\mathrm{kg} / \mathrm{ha}]$ was established on the basis of chemical analysis of the digested substrate. The chemical analysis of the digested substrate is given in Table 3 . The research trial studying effects of the digestate used as fertiliser was established by the method of blocks with four treatments and four replicates, plot size $1.5 \times 10 \mathrm{~m}\left(15 \mathrm{~m}^{2}\right)$. The trial treatments are given in Table 2.

Botanical composition - namely agro-botanical groups of grasses, legumes, other herbs and bare ground - was determined by the method of projective dominance in compliance with Maloch (1953) before each of the cuts. The plant species within the botanical groups were recorded. Grassland was utilised by three cuts a year: the $1^{\text {st }}$ cut - at the ear emergence of dominant grass species; the $2^{\text {nd }}$ cut -6 to 8 weeks later; the $3^{\text {rd }}$ cut -8 to 10 weeks after the $2^{\text {nd }}$ cut. Herbage samples were taken from all the treatments and cuts. The production was defined as fresh herbage weight at the research site. Chemical analysis was made of herbage oven-dried at $65^{\circ} \mathrm{C}$ and the production was determined as dry matter (DM) content. The sward quality was analysed in the samples taken at all the treatments and cuts. The following organic and mineral substances were determined: crude protein by the Kjeldahl method ( $\mathrm{N}$ $\times 6.25$ ); fibre by the Henneberg-Stohmann method; the contents of $\mathrm{P}, \mathrm{K}, \mathrm{Mg}$ and $\mathrm{Ca}$ were determined in accordance with the Slovak technical standard STN 467093 . The obtained data were subjected to analysis of variance (ANOVA) followed by post hoc comparison using the Tukey's HSD test (Statit Custom QC for Windows).

\section{RESULTS AND DISCUSSION}

Effects of different climatic conditions, grassland utilisation as well as the application of digested substrate as fertiliser on changed botanical composition, DM production and sward quality were found.

In 2009 , mean air temperature was $16.5^{\circ} \mathrm{C}$ and that is $1.1^{\circ} \mathrm{C}$ increase by comparison with $15.4^{\circ} \mathrm{C}$

$\mathrm{T}$ a

Trial treatments

\begin{tabular}{|c|c|}
\hline \multicolumn{2}{|c|}{ Trial treatments } \\
\hline Treatment 1 & Control (non-fertilised sward) \\
Treatment 2 & Fertilised sward*: $40 \mathrm{~kg} \mathrm{~N}+20 \mathrm{~kg} \mathrm{~N} / \mathrm{ha}$ (Batch 1) \\
Treatment 3 & Fertilised sward*: $40 \mathrm{~kg} \mathrm{~N}+20 \mathrm{~kg} \mathrm{~N} / \mathrm{ha}$ (Batch 2) \\
Treatment 4 & Fertilised sward*: $40 \mathrm{~kg} \mathrm{~N}+20 \mathrm{~kg} \mathrm{~N} / \mathrm{ha}$ (Batch 3) \\
\hline Batch 1 & $100 \%$ cattle / pig slurry \\
Batch 2 & $80 \%$ cattle / pig slurry $+20 \%$ preserved phytomass (dry mass) \\
Batch 3 & $60 \%$ cattle / pig slurry $+40 \%$ preserved phytomass (dry mass) \\
\hline
\end{tabular}

* $40 \mathrm{~kg} \mathrm{~N} / \mathrm{ha}$ - was applied to sward in the spring; $20 \mathrm{~kg} \mathrm{~N} / \mathrm{ha}$ - was applied to sward after the first cut 
in the year 2008. The maximum temperature ranged from $30.0^{\circ} \mathrm{C}$ (September) to $30.2^{\circ} \mathrm{C}$ (June and July). In 2008, rainfall over the growing season was 466 $\mathrm{mm}$ while the total annual rainfall was $966 \mathrm{~mm}$. In 2009, the rainfall over growing season decreased by $138 \mathrm{~mm}$ when compared with that in 2008 (Figure 1). In 2008 , the first research year, botanical composition did not show much change after the digestate application. The sward development was differing more in the following research year. The proportion of grasses as percentage increased at all the treatments and cuts (Table 4). The highest proportion of grasses $(62-73 \%)$ was recorded at the $3^{\text {rd }}$ cut. In 2008, Poa pratensis L. was the dominant grass species (14-15\%) and the proportion increased to $19 \%$ (Treatment 4 ) and $22 \%$ (Treatment 2) at the 1 st cut in 2009. Honsová et al. (2007) found a positive response of Poa pratensis L. on application of nitrogen fertiliser. There were more grass species expanding in sward in 2009, namely Festuca rubra L., Trisetum flavescens L., Lolium perenne L., Bromus erectus L., Festuca pratensis Huds. and also Dactylis glomerata $\mathrm{L}$ - this one especially at Treatment 4 in the $2^{\text {nd }}$ cut of 2009 . The $3^{\text {rd }}$ cut brought higher proportions of Festuca rubra L., Dactylis glomerata L. and Arrhenatherum elatius L. in 2009 than in 2008. The proportion of Bromus erectus L. in- creased to $8-14 \%$ in sward at the end of the growing season in 2009. This second research year showed a decrease in the proportion of legumes in sward at all the treatments, the most notable one at the $3^{\text {rd }}$ cut (Table 4). Vozár et al. (2012) reported that proportion of le-gumes decreased with increasing nitrogen rates. The dominant legume species were Trifolium repens $\mathrm{L}$. (at the control and the treatment with $100 \%$ slurry digestate applied) and Medicago falcata L. (at Treatments 3 and 4), Medicago sativa L. and Medicago lupulina L. were also present in the sward. The proportion of other herbs also decreased in sward in the second research year. The most marked decrease in the number of herb species (from $29 \%$ to $14 \%$ ) was recorded at Treatment 1 in the first cut in 2009. The dominant species were Achillea millefolium L., Geranium robertianum L., Silene inflata Sm., Plantago lanceolata $\mathrm{L}$. and Taraxacum officinale W. At all the treatments, the proportion of grasses was higher in 2009 than in 2008, but that of legumes and herbs decreased. This agrees with the data published by Holúbek et al. (2007) who reported that all the plant species of the phytocoenosis are stimulated at the start of fertiliser application and the growth intensity is related to the fertiliser types and rates. The application of high

T

The means of the chemical analyses results of the digested substrates

\begin{tabular}{|l|c|c|c|}
\hline \multirow{2}{*}{ Parameter } & \multicolumn{2}{|c|}{ Batch* } \\
\cline { 2 - 4 } & 1 & 2 & 3 \\
\hline Total nitrogen [g/kg] & 4.04 & 2.61 & 4.11 \\
$\mathrm{NO}_{3}^{-} \mathrm{N}[\mathrm{mg} / \mathrm{kg}]$ & 0.64 & 0.85 & 0.65 \\
$\mathrm{NH}_{4}^{+}-\mathrm{N}[\mathrm{g} / \mathrm{kg}]$ & 2.85 & 2.23 & 2.79 \\
Phosphorus [g/kg] & 0.68 & 0.18 & 0.74 \\
Potassium [g/kg] & 1.78 & 1.78 & 1.90 \\
Natrium [g/kg] & 0.45 & 0.61 & 0.53 \\
Calcium [g/kg] & 2.13 & 1.41 & 1.89 \\
Magnesium [g/kg] & 0.66 & 0.13 & 0.40 \\
$\mathrm{C} / \mathrm{N}$ ratio & 9.95 & 2.67 & 2.29 \\
$\mathrm{pH}$ & 7.48 & 7.36 & 7.35 \\
\hline
\end{tabular}

* Batch 1-100\% cattle/pig slurry; Batch $2-80 \%$ cattle/pig slurry $+20 \%$ preserved phytomass (dry mass); Batch $3-60 \%$ cattle/pig slurry $+40 \%$ preserved phytomass (dry mass) 
fertiliser rates increases the grass proportion, but legumes and herbs disappear from sward.

An increasing proportion of grasses as a result of increasing $\mathrm{N}$ rates corresponds with the conclusions of other authors (Vozár et al. 2012; Silvertown et al. 2006) who state that systematic fertilisation with higher $\mathrm{N}$ rates gradually results in the development of more simple, mainly grass populations.

The lowest dry matter production was found at the control in both research years. The total DM yield was $2.80 \mathrm{t} / \mathrm{ha}$ in 2008 , but only $1.92 \mathrm{t} / \mathrm{ha}$ in 2009. The data in Table 8 show significant effects of the years on DM production $(P<0.05)$. Vargová et al. (2012) reported that the application of nitrogen significantly increased the DM production nearly in all the cuts and years $(P<0.05)$ and influenced also the total yield over the research period. The variability in the yield increase under the rising $\mathrm{N}$ rates was found in agreement with Glab and Kacorzyk (2011) and other authors studying the grassland nutrition. The application of digestate increased the DM production in greater part of all cuts (Table 5). The total DM yield increased by $0.78 \mathrm{t} / \mathrm{ha}$ at Treatment 2 (the digested substrate from $100 \%$ slurry applied) in comparison with the control. The most marked increase in DM production was recorded at Treatment 4 where the digestate composed of $60 \%$ slurry with $40 \%$ phytomass was applied, as shown by the significant effects of the different rates $(P<0.05)$ on DM production (Table 8 ). In the first research year, the total yield was $5.03 \mathrm{t} / \mathrm{ha}$ (increased by $2.23 \mathrm{t} / \mathrm{ha}$ ) at Treatment $3(80 \%$ slurry with $20 \%$ phytomass digested substrate). The dry matter production was not evenly distributed at the treatments throughout the season. At all the treatments, DM production was low at the $3^{\text {rd }}$ cut, due to low rainfall and high temperatures during July, August and September (Figure 1). In 2009, the DM yields were lower at all the cuts and treatments, except for Treatment 3 at the $2^{\text {nd }}$ cut $(3.47 \mathrm{t} / \mathrm{ha})$. In 2009 , the highest DM yield (4.34 $\mathrm{t} / \mathrm{ha}$ ) was recorded at Treatment 3. But Nerušil et al. (2008) and Raus et al. (2012) reached conclusions in their several-year studies revealing that the yields increased gradually over the years with increasing $\mathrm{N}$ rates.

The crude protein $(\mathrm{CP})$ and fibre content are given in Table 6. In 2008, the CP content was rising at Treatments 3 and 4 throughout the $1^{\text {st }}, 2^{\text {nd }}$ and $3^{\text {rd }}$ cuts, respectively. In the second research year, the highest $\mathrm{CP}$ content was recorded in the $3^{\text {rd }}$ cut at all the treatments. The crude protein content was $175.5 \mathrm{~g} / \mathrm{kg}$ in the $3^{\text {rd }}$ cut at Treatment $3(80 \%$ slurry and $20 \%$ phytomass). Averaged over the years, the highest CP content $(155.7 \mathrm{~g} / \mathrm{kg})$ was found at Treat-

T a b 1 e 4

Botanical composition [\%] over the cuts and years

\begin{tabular}{|c|c|c|c|c|c|c|c|c|c|}
\hline \multirow{3}{*}{$\begin{array}{l}\text { Botanical } \\
\text { groups }\end{array}$} & \multirow{3}{*}{ Cuts } & \multicolumn{8}{|c|}{ Treatments* } \\
\hline & & 1 & 2 & 3 & 4 & 1 & 2 & 3 & 4 \\
\hline & & \multicolumn{4}{|c|}{2008} & \multicolumn{4}{|c|}{2009} \\
\hline \multirow{3}{*}{ Grasses } & $1^{\text {st }}$ & 47 & 51 & 44 & 43 & 69 & 70 & 62 & 66 \\
\hline & $2^{\text {nd }}$ & 52 & 57 & 45 & 51 & 66 & 60 & 53 & 63 \\
\hline & $3^{\text {rd }}$ & 57 & 58 & 49 & 48 & 73 & 68 & 65 & 62 \\
\hline \multirow{3}{*}{ Legumes } & $1^{\text {st }}$ & 22 & 24 & 31 & 30 & 13 & 14 & 20 & 20 \\
\hline & $2^{\text {nd }}$ & 23 & 22 & 29 & 26 & 15 & 21 & 22 & 19 \\
\hline & $3^{\text {rd }}$ & 22 & 26 & 33 & 31 & 10 & 13 & 21 & 23 \\
\hline \multirow{3}{*}{ Herbs } & $1^{\text {st }}$ & 29 & 25 & 23 & 23 & 14 & 16 & 17 & 14 \\
\hline & $2^{\text {nd }}$ & 25 & 21 & 26 & 23 & 18 & 19 & 24 & 17 \\
\hline & $3^{\text {rd }}$ & 20 & 16 & 18 & 19 & 14 & 15 & 13 & 13 \\
\hline \multirow{3}{*}{$\begin{array}{l}\text { Bare } \\
\text { ground }\end{array}$} & $1^{\text {st }}$ & 2 & 0 & 2 & 4 & 4 & 0 & 1 & 0 \\
\hline & $2^{\text {nd }}$ & 0 & 0 & 0 & 0 & 1 & 0 & 1 & 1 \\
\hline & $3^{\text {rd }}$ & 1 & 0 & 0 & 2 & 3 & 4 & 1 & 2 \\
\hline
\end{tabular}

* See Table 1 
ment 3 ( $80 \%$ slurry and $20 \%$ phytomass), as shown by the significant effects $(P<0.05)$. The lowest CP content $(127.6 \mathrm{~g} / \mathrm{kg})$ was recorded at the treatment with the digestate from $100 \%$ slurry applied. Effect of the year was confirmed on the crude protein content (Table 9).
Hejcman et al. (2010) and Holúbek et al. (2007) reported that the content of nutrients in herbage DM decreased with the reduction of available nutrients in soil and decreased also with increasing yield due to the so called dilution effect in the grown-up biomass. The quality of dry matter is defined by the

T

Dry matter yield $[\mathrm{t} / \mathrm{ha}]$ at the cuts

\begin{tabular}{|c|c|c|c|c|c|c|c|c|}
\hline \multirow{3}{*}{ Cuts } & \multicolumn{8}{|c|}{ Treatments* } \\
\hline & \multicolumn{4}{|c|}{2008} & \multicolumn{4}{|c|}{2009} \\
\hline & 1 & 2 & 3 & 4 & 1 & 2 & 3 & 4 \\
\hline $1^{\text {st }}$ & 0.61 & 1.27 & 1.50 & 1.65 & 0.28 & 0.38 & 0.81 & 0.76 \\
\hline $2^{\text {nd }}$ & 1.83 & 1.88 & 3.05 & 3.63 & 1.63 & 1.35 & 3.47 & 2.64 \\
\hline $3^{\text {rd }}$ & 0.36 & 0.43 & 0.40 & 0.75 & 0.01 & 0.02 & 0.06 & 0.08 \\
\hline$\sum$ cuts & 2.80 & 3.58 & 4.95 & 6.03 & 1.92 & 1.75 & 4.34 & 3.48 \\
\hline Treatments* & \multicolumn{8}{|c|}{ Mean } \\
\hline 1 & \multicolumn{8}{|c|}{$2.36^{\mathrm{a}}$} \\
\hline 2 & \multicolumn{8}{|c|}{$2.66^{\mathrm{ab}}$} \\
\hline 3 & \multicolumn{8}{|c|}{$4.64^{\mathrm{b}}$} \\
\hline 4 & \multicolumn{8}{|c|}{$4.75^{b}$} \\
\hline
\end{tabular}

The values in the same row with different superscript letters are significantly different at $P<0.05$ level for each variable (Tukey's HSD test)

* see Table 1

T

Crude protein and fibre content in phytomass dry matter $[\mathrm{g} / \mathrm{kg}]$

\begin{tabular}{|c|c|c|c|c|c|c|c|c|c|}
\hline \multirow{3}{*}{ Years } & \multirow{3}{*}{ Cuts } & \multicolumn{8}{|c|}{ Treatments* } \\
\hline & & 1 & 2 & 3 & 4 & 1 & 2 & 3 & 4 \\
\hline & & \multicolumn{4}{|c|}{ Crude protein } & \multicolumn{4}{|c|}{ Fibre } \\
\hline \multirow{3}{*}{2008} & $1^{\text {st }}$ & 121.8 & 113.3 & 138.7 & 118.6 & 135.9 & 186.4 & 193.7 & 216.8 \\
\hline & $2^{\text {nd }}$ & 145.3 & 133.7 & 149.3 & 125.1 & 194.2 & 177.7 & 232.9 & 247.9 \\
\hline & $3^{\text {rd }}$ & 116.0 & 104.5 & 154.9 & 140.0 & 156.2 & 172.9 & 173.1 & 210.5 \\
\hline \multirow{3}{*}{2009} & $1^{\text {st }}$ & 158.3 & 131.2 & 170.7 & 135.4 & 194.7 & 206.9 & 197.8 & 233.3 \\
\hline & $2^{\text {nd }}$ & 153.3 & 122.2 & 144.9 & 132.3 & 191.4 & 231.3 & 247.3 & 249.5 \\
\hline & $3^{\text {rd }}$ & 143.6 & 161.1 & 175.6 & 172.9 & 191.3 & 182.6 & 197.5 & 190.3 \\
\hline \multicolumn{2}{|c|}{ Mean } & $139.7^{\mathrm{ab}}$ & $127.6^{\mathrm{a}}$ & $155.7^{\mathrm{b}}$ & $137.3^{\mathrm{ab}}$ & $172.3^{\mathrm{a}}$ & $192.9^{\mathrm{ab}}$ & $207.0^{\mathrm{bc}}$ & $224.7^{\mathrm{c}}$ \\
\hline
\end{tabular}

The values in the same row with different superscript letters are significantly different at $P<0.05$ level for each variable (Tukey's HSD test)

* see Table 1 


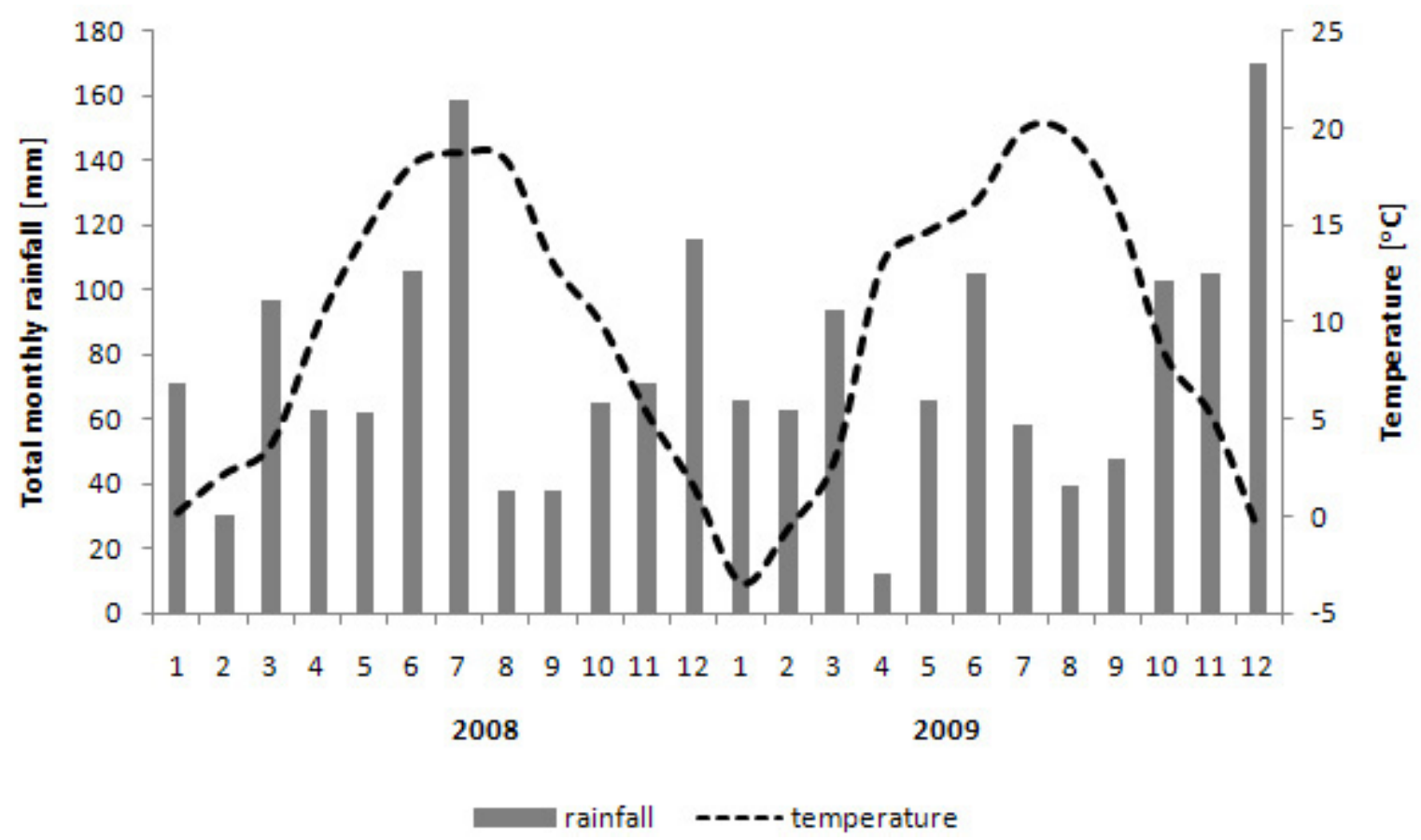

Figure 1 Mean monthly temperature $\left[{ }^{\circ} \mathrm{C}\right]$ and total monthly rainfall $[\mathrm{mm}]$

mineral and organic composition (Whitehead 2000). As defined by Klapp (1971), the phosphorus (P) content in DM of above-ground phytomass is approximately $2.8 \mathrm{~g} / \mathrm{kg}$. Holúbek et al. (2007) specified an acceptable $\mathrm{P}$ content in $1 \mathrm{~kg} \mathrm{DM}$ ranging between 2.8 and $3.3 \mathrm{~g} / \mathrm{kg}$ and acceptable Ca content 4 and $11 \mathrm{~g} / \mathrm{kg}$. The content of P recorded throughout the research agreed with this range. The highest content of potassium $(\mathrm{K})$ was always recorded at the $2^{\text {nd }}$ cut and then started decreasing at Treatments 3 and 4 towards the end of growing seasons. While the P content was decreasing at the end of growing season, the calcium $(\mathrm{Ca})$ content was rising. Table 9 shows the any significant effects of the cuts on the mean content of crude protein and $\mathrm{K}$. The highest $\mathrm{Ca}$ content $(16.6 \mathrm{~g} / \mathrm{kg})$ was recorded at Treatment 3. Fiala (2002) specified that $\mathrm{Mg}$ content is needed in the concentration $3 \mathrm{~g} / \mathrm{kg}$ and content of $P 3.5 \mathrm{~g} / \mathrm{kg}$. The content of magnesium $(\mathrm{Mg})$ decreased at the control. By comparison of all the treatments, the highest content of $\mathrm{P}$ and $\mathrm{K}$ was found at the control, while the highest $\mathrm{Ca}$ and $\mathrm{Mg}$ contents were found at Treatment 3 (Table 7). Effect of the different rates was confirmed only on K content, any significant effects on the other elements were not found. Fiala (2002) reports that the long-term application of fertiliser has influence on the content of mineral substances in total and at the individual cuts as well. The rising rates of nitrogen fertiliser are increasing the content of $\mathrm{N}$ and $\mathrm{P}$, but decreasing the content of $\mathrm{Ca}, \mathrm{Mg}$ and $\mathrm{K}$. The three-cut utilisation of sward is characteristic of increasing content of $\mathrm{Ca}$ and $\mathrm{Mg}$ and decreasing $\mathrm{K}$ content from the first to the last cut.

\section{CONCLUSIONS}

New ways of using the digested substrate as fertiliser applied to grassland were studied over 2008-2009 and the research results were concluded as follows:

In 2009, the proportion of grasses in sward increased, but that of legumes and other herbs decreased.

In comparison with the control, the highest increase in DM production was found at Treatment 4 
$\mathrm{T}$ a

The content of macroelements $[\mathrm{g} / \mathrm{kg}]$ in phytomass dry matter at the cuts (mean of 2 years)

\begin{tabular}{|c|c|c|c|c|c|}
\hline \multirow{2}{*}{ Minerals } & \multirow{2}{*}{ Cuts } & \multicolumn{4}{|c|}{ Treatments* } \\
\hline & & 1 & 2 & 3 & 4 \\
\hline \multirow{3}{*}{$\mathrm{P}$} & $1^{\text {st }}$ & 3.3 & 3.2 & 3.3 & 2.9 \\
\hline & $2^{\text {nd }}$ & 4.1 & 3.8 & 3.9 & 3.6 \\
\hline & $3^{\text {rd }}$ & 3.6 & 3.6 & 3.4 & 3.2 \\
\hline \multirow{3}{*}{$\mathrm{K}$} & $1^{\text {st }}$ & 22.8 & 20.8 & 18.7 & 21.9 \\
\hline & $2^{\text {nd }}$ & 24.9 & 22.8 & 20.1 & 22.9 \\
\hline & $3^{\text {rd }}$ & 22.4 & 22.1 & 17.1 & 15.9 \\
\hline \multirow{3}{*}{$\mathrm{Ca}$} & $1^{\text {st }}$ & 7.9 & 6.9 & 8.9 & 8.6 \\
\hline & $2^{\text {nd }}$ & 9.2 & 9.7 & 11.7 & 10.2 \\
\hline & $3^{\mathrm{rd}}$ & 12.7 & 13.9 & 16.6 & 14.3 \\
\hline \multirow{3}{*}{$\mathrm{Mg}$} & $1^{\text {st }}$ & 3.7 & 2.9 & 3.7 & 3.1 \\
\hline & $2^{\text {nd }}$ & 3.2 & 3.2 & 3.4 & 2.9 \\
\hline & $3^{\mathrm{rd}}$ & 3.2 & 3.5 & 4.1 & 3.8 \\
\hline
\end{tabular}

* See Table 1

T

The effect of years, cuts and treatments on dry matter yield [ $\mathrm{t} / \mathrm{ha}]$

\begin{tabular}{|c|c|c|c|}
\hline Effect & Factor & Dry matter yield & SEM \\
\hline \multirow{2}{*}{ Years } & 2008 & $1.45^{\mathrm{b}}$ & 1.13 \\
& 2009 & $0.96^{\mathrm{a}}$ & 0.51 \\
\hline \multirow{3}{*}{ Cuts } & $1^{\text {st }}$ & $0.92^{\mathrm{b}}$ & 0.88 \\
& $2^{\text {nd }}$ & $2.44^{\mathrm{c}}$ & 0.26 \\
\hline \multirow{3}{*}{ Treatments* } & $3^{\text {rd }}$ & $0.26^{\mathrm{a}}$ & 0.75 \\
& 1 & $0.80^{\mathrm{a}}$ & 0.72 \\
& 2 & $0.89^{\mathrm{ab}}$ & 1.42 \\
\hline
\end{tabular}

The values in the same row with different superscript letters are significantly different at $P<0.05$ level for each variable (Tukey's HSD test)

SEM - standard error of the mean

*see Table 1 
$\mathrm{T}$ a $\quad$ b $1 \begin{array}{llll} & \text { e } & 9\end{array}$

The effects of fertiliser application, cuts, and years on the nutrient content $[\mathrm{g} / \mathrm{kg}]$

\begin{tabular}{|c|c|c|c|c|c|c|}
\hline Factor & Crude protein & Fibre & $\mathrm{P}$ & $\mathrm{K}$ & $\mathrm{Ca}$ & $\mathrm{Mg}$ \\
\hline \multicolumn{7}{|c|}{ Treatments* } \\
\hline 1 & $139.7^{\mathrm{ab}}$ & $172.3^{\mathrm{a}}$ & $3.7^{\mathrm{a}}$ & $23.4^{\mathrm{b}}$ & $9.9^{\mathrm{a}}$ & $3.4^{\mathrm{a}}$ \\
\hline 2 & $127.6^{\mathrm{a}}$ & $192.9^{\mathrm{ab}}$ & $3.5^{\mathrm{a}}$ & $21.9^{\mathrm{ab}}$ & $10.1^{\mathrm{a}}$ & $3.2^{\mathrm{a}}$ \\
\hline 3 & $155.7^{\mathrm{b}}$ & $207.1^{\mathrm{bc}}$ & $3.5^{\mathrm{a}}$ & $18.6^{\mathrm{a}}$ & $12.4^{\mathrm{a}}$ & $3.7^{\mathrm{a}}$ \\
\hline 4 & $137.4^{\mathrm{ab}}$ & $224.7^{c}$ & $3.2^{\mathrm{a}}$ & $20.3^{\mathrm{ab}}$ & $11.0^{\mathrm{a}}$ & $3.4^{\mathrm{a}}$ \\
\hline SEM & 11.62 & 22.19 & 0.18 & 2.06 & 1.12 & 0.22 \\
\hline \multicolumn{7}{|c|}{ Cuts } \\
\hline $1^{\text {st }}$ & $136.0^{\mathrm{a}}$ & $195.7^{\mathrm{ab}}$ & $3.2^{\mathrm{a}}$ & $21.1^{\mathrm{a}}$ & $8.1^{\mathrm{a}}$ & $3.4^{\mathrm{ab}}$ \\
\hline $2^{\text {nd }}$ & $138.3^{\mathrm{a}}$ & $217.8^{b}$ & $3.8^{\mathrm{b}}$ & $22.7^{\mathrm{a}}$ & $10.2^{\mathrm{a}}$ & $3.1^{\mathrm{a}}$ \\
\hline $3^{\mathrm{rd}}$ & $146.1^{\mathrm{a}}$ & $184.3^{\mathrm{a}}$ & $3.4^{\mathrm{a}}$ & $19.4^{\mathrm{a}}$ & $14.4^{\mathrm{b}}$ & $3.6^{\mathrm{b}}$ \\
\hline SEM & 5.28 & 17.01 & 0.34 & 1.66 & 3.18 & 0.25 \\
\hline \multicolumn{7}{|c|}{ Years } \\
\hline 2008 & $130.1^{\mathrm{a}}$ & $191.5^{\mathrm{a}}$ & $3.6^{\mathrm{a}}$ & $20.3^{\mathrm{a}}$ & $10.7^{\mathrm{a}}$ & $3.4^{\mathrm{a}}$ \\
\hline 2009 & $150.1^{\mathrm{b}}$ & $206.9^{\mathrm{a}}$ & $3.4^{\mathrm{a}}$ & $21.8^{\mathrm{a}}$ & $11.0^{\mathrm{a}}$ & $3.4^{\mathrm{a}}$ \\
\hline SEM & 14.17 & 10.94 & 0.14 & 1.11 & 0.19 & 0.05 \\
\hline
\end{tabular}

The values in the same row with different superscript letters are significantly different at $\mathrm{P}<0.05$ level for each variable (Tukey's HSD test)

SEM - standard error of the mean

*see Table 1

where the digestate of $60 \%$ slurry and $40 \%$ phytomass was applied.

Using the digested substrate as fertiliser had positive effects on yield. The lowest CP content of all the research treatments was found at that with $100 \%$ slurry applied.

The highest content of $\mathrm{P}$ and $\mathrm{K}$ was recorded at the control, while the highest content of $\mathrm{Ca}$ and $\mathrm{Mg}$ was found at Treatment 3.

Considering the parameters of quality (crude protein, fibre, minerals) and quantity, the digested substrate appears to be an optimum utilisation regime for the grassland nutrition. We recommend the application of digested substrate which input material contains $20-40 \%$ of phytomass.

Acknowledgements: The presented research was carried out as a part of the research project of the CVRV [Plant Production Research Center] Piešt’any - VÚTPHP [Grassland and Mountain Agriculture Research Institute] Banská Bystrica named „Com- petitiveness and ecologisation of crop production in the regions of Slovakia through the systems of management on agricultural land and by innovating the constituents of crop growing technologies", No. UO 27/09105 01/0910510.

\section{REFERENCES}

BRAUN, R. 2007. Anaerobic digestion: a multi-faceted process for energy, environmental management and rural development. In RANALLI, P. (Ed.) Improvement of crop plants for industrial end uses. Dordrecht : Springer, pp. 335-416. ISBN-10 1-4020-5486-6.

DIETERICH, B. - FINNAN, J. - FROST, P. - GILKINSON, S. - MÜLLER, S. 2012. The extent of methane (CH4) emissions after fertilisation of grassland with digestate. In Biology and Fertility of Soils, vol. 48, no. 8, pp. 981-985. DOI: 10.1007/s00374-012-07141.

FIALA, J. 2002. Development of ecological and yield stability of semi-natural grassland by its long-term fertilization and utilization. In Grassland Ecology VI: Proceedings of the International Scientific Con- 
ference. Banská Bystrica : VÚTPHP, pp.124-137. ISBN 80-968890-7-9.

GLĄB, T. - KACORZYK, P. 2011. Root distribution and herbage production under different management regimes of mountain grassland. In Soil and Tillage Research, vol. 113, no. 2, pp. 99-104.

HANÁČKOVÁ, E. - SLAMKA, P. 2008. Vplyv hnojenia fermentovaným biokalom na úrodu a výživnú hodnotu nadzemnej fytomasy kukurice siatej (Zea mays L.) [Influence of fertilization with fermented biosludge on the yield and nutritive value of aboveground maize (Zea mays L.) phytomass]. In Journal of Central European Agriculture, vol. 9, 2008, no. 3, pp. 609-614.

HEJCMAN, M. - SZAKOVÁ, J. - SCHELlBERG, J. - TLUSTOŠ, P. 2010. The Rengen Grassland Experiment: relationship between soil and biomass chemical properties, amount of elements applied, and their uptake. In Plant and Soil, vol. 333, 2010, pp. 163179. DOI: $10.1007 / \mathrm{s} 11104-010-0332-3$.

HOLÚBEK, R. - JANČOVIČ, J. - GREGOROVÁ, H. - NOVÁK, J. - ĎURKOVÁ, E. - VOZÁR, L. 2007. Krmovinárstvo - manažment pestovania a využivanie krmovin [Forage production - management of cropgrowing and utilisation]. 1. vyd. Nitra: SPU, $420 \mathrm{pp}$. ISBN 978-80-8069-911-6.

HONSOVÁ, D. - HEJCMAN, M. - KLAUdisOVÁ, M. - PAVLŮ, V. - HAKL, J. 2007. Species composition of an alluvial meadow after 40 years of applying nitrogen, phosphorus and potassium fertilizer. In Preslia, vol. 79, no. 4, pp. 245-258.

KLAPP, E. 1971. Wiesen und Weiden. Berlin, Hamburg : Paul Parey Verlag, 620 pp. ISBN 3-489-72510-7.

LEHTOMAKI, A. - HUTTUNEN, S. - LEHTINEN, T.M. - RINTALA, J.A. 2008. Anaerobic digestion of grass silage in batch leach bed processes for methane production. In Bioresource Technology, vol. 99, no. 8, pp. 3267-3278.

MALOCH, M. 1953. Krmovinárstvo [Forage production]. Bratislava: SPN, 1953. $616 \mathrm{p}$.

NERUŠIL P. - KOHOUTEK A. - KOMÁREK P. ODSTRČILOVÁ V. 2008: Effects of utilisation intensity and fertilization level on forage production and quality of permanent grassland on a fluvisoil. In Acta Universitatis Agriculturae et Silviculturae Mendelianae Brunensis, vol. 56, no. 5, pp. 153-162.

ONDREJČÍKOVÁ, Z. - REŽO, L. - MAREČEK, J. POSPIŠIL, R. 2009. Vplyv biokalu na kvantitatívne a kvalitatívne parametre slnečnice ročnej [The influence of decayed waste on quantitative and qualitative parameters of sunflower]. In Acta fytotechnica et zootechnica, vol. 12, no. Mimoriadne - Special, pp. 512-516.

POSPÍŠIL, R. - MANO, M. 2007. The influence of application biosledge for production and quality maize for silage. In Súčasnost' a perspektivy krmovinárskeho výskumu a vzdelávaniav multifunkčnom využivaníkrajiny: proceedings of scientific conference. Nitra : SPU, pp. 231-233. ISBN 978-80-8069-929-1.

POSPÍŠIL, R. et al. 2009. Využitie biokalu pri pestovaní polných plodin [The utilisation of decayed waste in growing field crops]. Nitra: SPU, 186 p. ISBN 97880-552-0289-1.

POSPÍŠIL, R. - CANDRÁKOVÁ, E. - ONDREJČÍKOVÁ, Z. 2011. Účinok hnojenia digestátom na energetickú efektívnost' produkcie repy cukrovej [Effect of digestate fertilization on energy of sugar production]. In Listy Cukrovarnické a Řepařské, vol. 127, no. 7-8, pp. 219-222.

PROCHNOW, A. - HEIERMANN, M. - PLÖCHL, M. LINKE, B. - IDLER, C. - AMON, T. - HOBBS, P.J. 2009. Bioenergy from permanent grassland - A review: 1. Biogas. In Bioresource Technology, vol. 100, no. 21, pp. 4931-4944.

RAUS, J. - KNOT, P. - HRABĚ, F. 2012. Effect of fertilization and harvest frequency on floristic composition and yields of meadow stand. In Acta Universitatis Agriculturae et Silviculturae Mendelianae Brunensis, vol. 60, no. 5, pp. 181-186.

SALMINEN, E. - RINTALA, J. - HARKONEN, J. - KUITUNEN, M. - HOGMANDER, H. - OIKARI, A. 2001. Anaerobically digested poultry slaughterhouse wastes as fertiliser in agriculture. In Bioresource Technology, vol. 78 , no. 1 , pp. $81-88$.

SILVERTON, J. - POULTON, P. - JOHNSTON, E. - EDWARDS, G. - HEARD, M. - BISS, P.M. 2006. The Park Grass Experiment 1856-2006: its contribution to ecology. In Journal of Ecology, vol. 94, no. 4, pp. 801-814.

TANI, M. - SAKAMOTO, N. - KISHIMOTO, T. - UMETSU, K. 2006. Utilization of anaerobically digested dairy slurry combined with other wastes following application to agricultural land. In International Congress Series, vol. 1293, pp. 331-334.

TILVIKIENE, V. - KADŽIULIENE, Ž. - DABKEVICIUS, Z. 2010. Effect of digestate application on cocksfoot on biomass production and quality. In Treatment and use of non conventional organic residuesin agriculture, $14^{\text {th }}$ Ramiran International conference. Lisboa, Portugal, October 12.-15., pp. 1-4.

TILVIKIENE, V. - KADŽIULIENE, Ž. - DABKEVICIUS, Z. 2011. Digestate application on cocksfoot (Dactylis glomerata L.) swards - effects on yield, $\mathrm{N}$ content and $\mathrm{C} / \mathrm{N}$ ratio. In Grassland Science of Europe, vol. 16, pp. 383-385.

VARGOVÁ, V. - KOVÁČIKOVÁ, Z. - MICHALEC, M. 2012. Effects of rates and nutrient ratios on production and quality of phytomass at fertiliser application to an alluvial meadow. In Agriculture (Pol'nohospodárstvo), vol. 58 , no. 1 , pp. 1-10. DOI: 10.2478/v10207-012$0001-z$.

VOĆA, N. - KRIČKA, T. - ĆOSIĆ, T. - RUPIĆ, V. JUKIĆ, Ž. - KALAMBURA, S. 2005. Digested residue as a fertilizer after the mesophilic process of anaerobic digestion. In Plant, Soil and Environment, vol. 51, no. 6, pp. 262-266.

VOZÁR, L. - JANČOVIČ, J. - KOVÁR, P. - BAČOVÁ, S. 2012. Adaptability of permanent grassland to drought. In Journal of Life Sciences, vol. 6, no. 11, pp. 10571060 .

WANG, L. - LI, Y. - CHEN, P. - MIN, M. - CHEN, Y. - ZHU, J. - RUAN, R. R. 2010. Anaerobic digested dairy manure as a nutrient supplement for cultivation of 
oil-rich green microalgae Chlorella sp. In Bioresource Technology, vol. 101, no. 8, pp. 2623-2628.

WHITEHEAD, D.C. 2000. Nutrients elements in grassland: soil - plant - animal relationships. Wallingford, UK: CABI Publishing, 369 pp. ISBN 0-85199-437-7.

World reference base for soil resources. 2006. A framework for international classification, correlation and communication. No. 103, FAO, Rome, 145 pp. ISBN 92-5-105511-4.
WULF, S. - MAETING, M. - CLEMENS, J. 2002. Application technique and slurry co-fermentation effects on ammonia, nitrous oxide, and methane emission after spreading: II. Greenhouse gas emission. In Journal of Environmental Quality, vol. 31, no. 6, pp. 1795-1801.

Received: February, $22^{\text {th }}, 2013$ 